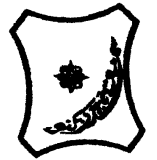

Bayero Journal of Pure and Applied Sciences, 5(1): 1 - 4

Received: May 2011

Accepted: May 2012

ISSN $2006-6996$

\title{
REACTION OF PEARL MILLET INFECTED WITH DOWNY MILDEW (SCLEROSPORA GRAMINICOLA (SACC.) SCHROET) INTERCROPPED COWPEA WITH ON DAYS TO 50\% HEADING AND GRAIN YIELD IN THE SAVANNA ZONE OF NORTHERN NIGERIA
}

\author{
*Gaya, A. G ${ }^{1}$., Adebitan, S. A. ${ }^{2}$ and Gurama, A. U. ${ }^{2}$ \\ ${ }^{1}$ Department of Crop Science, Faculty of Agriculture and Agricultural Technology, Kano University of Science and \\ Technology, Wudil, Kano State, Nigeria \\ ${ }^{2}$ Crop Production Programme, School of Agriculture, Abubakar Tafawa Balewa University Bauchi, Nigeria \\ *Correspondence author: abbagaya@yahoo.com
}

\begin{abstract}
Field trials were carried out at the Teaching and Research farm of Kano University of Science and Technology Wudil with three pearl millet varieties in 2003, 2004 and 2005 rainy seasons to find out the reaction of cowpea intercropped with pearl millet infected with downy mildew on days to $50 \%$ heading and grain yield. The experiment was a $3 \times 2$ factorial in randomized blocks of six plots with three pearl millet varieties (LCIC 9702, Ex-Borno and Zango) and each variety was intercropped with a cowpea and planted sole making six treatments. Data collected on days to $50 \%$ heading and grain yield were subjected to T-test for the separation of means of sole and intercropped to bring out the differences between them at $1 \%$ and $5 \%$ levels of significance. Results showed that intercropped LCIC pearl millet variety had significant/y $(P \leq 0.05)$ more days to $50 \%$ heading than other varieties either planted sole or intercropped in 2004. Similarly, from the combined result, it showed that intercropped LCIC pearl millet variety had significant/y $(P \leq 0.05)$ more days to $50 \%$ heading than other varieties either solely planted or intercropped. Maximum grain yield was however obtained from sole Zango and intercropped LCIC 9702 pearl millet varieties. Combined result shows only intercropped LCIC 9702 had significantly (P $\leq 0.05)$ maximum grain yield than other pearl millet varieties. It is imperative to grow sole LCIC 9702 pearl millet variety than intercropped with cowpea for less number of days to $50 \%$ heading. But for maximum grain yield, it is advisable to grow sole Zango and intercrop LCIC 9702 with cowpea.
\end{abstract}

Keywords: Downy mildew, grain yield, 50\% heading, intercropping and pearl millet

\section{INTRODUCTION}

Pearl millet (Pennisetum glaucum (L.) R. Br.) has traditionally been an important grain, forage and stover crop primarily in the arid and sub-tropical regions of the world. It is the world's six most important cereal crop, providing diet to about five hundred million people in the arid and semi-arid tropics particularly in India (Bilquez, 1979; Nwasike, et al., 1982; Yayock, et al., 1988 and NRC, 1996). Over 40 percent of land sown annually to cereals is devoted to millet (Ikwelle, 1998).

Nwasike (1988) reported that as the climate becomes drier pearl millet production exceeds that of sorghum due to its draught-tolerant character and the reverse is the case as rainfall increases. Being able to thrive where habitats are harsh, it is perhaps the best of all life-supporting grain (FAO, 1992). This report further pointed out that it yields reliably well in regions too hot and too dry to consistently support good yield of maize or sorghum. Already, the crop has gained ground into the hotter and drier part of Latin America, Central Asia, the Middle East, Australia and West Africa (NRC, 1996). The world area planted to millet is about 65 million hectares, with the major part in India and Africa (Nene and Singh, 1975). The area sown to the crop in West Africa is estimated at 12 million hectares, while in Nigeria, millet is cultivated on 5 million hectares (FAO, 1992), equivalent to 20.84 percent of the 23.99 million hectares of the country's total arable land.

Pearl millet production in Nigeria increased gradually between 1985 and 1994, reached a peak in 1988 and 1990, and than declined (CBN, 1994). The report further shows that the increase may be attributed to the cumulative effects of subsidies associated with National Food Production Programme, while the decline may be due to the effects of reduction of such subsidies. The aims of research is to find out the reaction of intercropping cowpea with pearl millet infected with downy mildew on days to $50 \%$ heading and grain yield.

\section{MATERIALS AND METHODS}

The trial was carried out at the teaching and research farm of Kano University of Science and Technology Wudil (Latitude $10^{\circ} 33^{\prime} \mathrm{S}$, Longitude $7^{\circ} 34^{\prime} \mathrm{N}$ to $9^{\circ} 24^{\prime} \mathrm{E}$; elevation 427-428m) (KNARDA, 2003) in 2003, 2004 and 2005 rain seasons. Three pearl millet varieties LCIC 9702, Ex-Borno and Zango were used for the trial throughout the years. The main purposes for choosing these varieties were because of having the highest incidence and severity of downy mildew and moreover, are widely grown in the Sudano-Sahelian zone of northern Nigeria (Grema and Odo, 1998). 
Before fertilizer application and planting, soil samples were randomly collected from the trial site using soil auger at the depth of $20 \mathrm{~cm}$ for soil physicochemical analysis. The land was prepared and all the cultural practices of pearl millet were carried out manually. Seeds were treated with Apron Plus at the rate of $30 \mathrm{~g} / \mathrm{kg}$ of the seeds before planting to control pre- and post-emergence damping-off of seedlings. Five millet seeds were planted in June (beginning of the rainy season) at a spacing of $75 \times 30 \mathrm{~cm}$ making 5 rows of pearl millet. Missing stands were supplied at seven days after sowing. The seedlings were thinned to two seedlings/hill two weeks after sowing. Two weedings were carried out at the second and seventh week after sowing, respectively. Each of the three chosen pearl millet varieties was intercropped with a cowpea variety (IT97K-499-35) because of its resistance to striga, tolerance to insects and high yielding (Mehrotra and Aggarwal, 2006) as well as planted sole in order to know the reaction of downy mildew infected pearl millet when intercropped with cowpea on grain yield. The cowpea was intercropped between the pearl millet rows. Two seeds of cowpea (IT97K-499-35) were planted at a spacing of $75 \times 20$ $\mathrm{cm}$. Super Plus 280 EC insecticide was sprayed two times (second and seventh week after sowing) on the cowpea plants against maruca pod borer and pod sucking bugs. The active ingredients for the insecticidal spray are cypermethrin $30 \mathrm{~g}$ and dimethoate $250 \mathrm{~g}$. Downy mildew infected pearl millet were placed on the aerial parts of the plants for effective infection since the pearl millet seeds used were not previously infected with the disease. Moreover, conidial suspension of the cultured pathogens $\left(10^{6}\right.$ spores $\left.\mathrm{mL}^{-1}\right)$ was sprayed on the plants at 7 days old ( Singh et al., 1997) to ensure that maximum infection took place during the trial (Williams et al., 1981). This method provides uniform distribution of sporangial inoculum throughout the test materials during the infection period (early seedling stage) in a natural manner.

The experimental design was a $3 \times 2$ factorial in randomized blocks of 6 plots with the following factors: three pearl millet varieties (LCIC 9702, ExBorno and Zango) and each variety was intercropped with a cowpea and planted solely making 6 treatments. All the treatments were replicated four times. Each plot measured $5 \mathrm{~m} \times 5 \mathrm{~m}\left(25 \mathrm{~m}^{2}\right)$ with $20.25 \mathrm{~m}^{2}$ effective net plot having six rows of pearl millet with 15 stands and six rows of cowpea with 24 stands. There were $1 \mathrm{~m}$ pathways between the replications.

Data were collected on days to $50 \%$ flowering by counting the number of days when $50 \%$ of the plants in a net plot have produced heads. Grain yield $(\mathrm{kg} / \mathrm{ha})$ was obtained by cutting and drying (under the sun) the heads of pearl millet after maturity (by observation) which were later threshed (with mortar and pestle) and weighed using an electric weighing balance from each plot.

Data collected were subjected to paired Ttest to separate the means of sole and intercropping to bring out the differences between them.

\section{RESULTS}

Reaction of intercropping cowpea with pearl millet infected with downy mildew (Sclerospora graminicola (Sacc.) Schroet) on days to $\mathbf{5 0 \%}$ heading

Result on the effect of intercropping pearl millet varieties with cowpea on days to $50 \%$ heading is presented in Table 1. It shows that no significant difference among intercropped and sole pearl millet varieties on days to $50 \%$ heading in 2003 and 2005, but LCIC 9702 pearl millet variety intercropped with cowpea had significantly more days to $50 \%$ heading than other varieties either solely planted or intercropped in 2004. Similarly, from the combine result, the same variety intercropped with cowpea also showed significantly more days to $50 \%$ than other pearl millet varieties which started heading earlier.

Reaction of intercropping cowpea with pearl millet infected with downy mildew (Sclerospora graminicola (Sacc.) Schroet) on days to $50 \%$ heading

Maximum grain yield was however significantly $(P \leq 0.05)$ obtained from the sole Zango and intercropped LCIC 9702 pearl millet varieties in 2003 and 2004 respectively (Table 2 ) while no significant difference between intercropped and sole pearl millet varieties in 2005. Combine result further shows that intercropped LCIC 9702 pearl millet had significantly more grain yield than other pearl millet varieties.

\section{DISCUSSION}

LCIC 9702 pearl millet intercropped with cowpea had more days to $50 \%$ heading in 2004 as well as from the combine result. Based on this research, it shows that an improved variety intercropped with cowpea took longer days to start heading than the local landrace varieties either intercropped or solely planted. It may be possible that when intercropped, the nitrogen-fixing ability of the cowpea benefits the pearl millet (Harper, 1983) which tends to defer its maturity and badly ripened (Hall, 2002). But this contradicts other varieties used in this research which showed least days to $50 \%$ heading even when intercropped with cowpea. 
Bajopas Volume 5 Number 1 June, 2012

Table 1: Reaction of intercropping cowpea with pearl millet infected with downy mildew (Sclerospora graminicola (Sacc.) Schroet) on days to 50\% heading for three years

\begin{tabular}{|c|c|c|c|c|c|c|c|c|c|c|c|c|}
\hline \multirow{3}{*}{$\begin{array}{l}\text { Year } \\
\text { Variety }\end{array}$} & \multicolumn{9}{|c|}{ Days to $50 \%$ heading } & \multirow{2}{*}{\multicolumn{3}{|c|}{ Combine }} \\
\hline & \multicolumn{3}{|c|}{2003} & \multicolumn{3}{|c|}{2004} & \multicolumn{3}{|c|}{2005} & & & \\
\hline & $\begin{array}{l}\text { LCIC } \\
9702 \\
\end{array}$ & Ex-Borno & $\overline{\text { Zango }}$ & $\begin{array}{l}\text { LCIC } \\
9702 \\
\end{array}$ & Ex-Borno & Zango & $\begin{array}{l}\text { LCIC } \\
9702 \\
\end{array}$ & Ex-Borno & Zango & $\begin{array}{l}\text { LCIC } \\
9702 \\
\end{array}$ & Ex-Borno & Zango \\
\hline \multicolumn{13}{|l|}{ Parameter } \\
\hline Intercopping & 61.90 & 60.25 & 67.75 & 61.25 & 59.75 & 67.75 & 60.50 & 60.50 & 69.25 & 61.08 & 60.17 & 68.25 \\
\hline S/cropping & 59.25 & 62.50 & 67.25 & 59.50 & 60.75 & 67.75 & 60.25 & 61.00 & 69.75 & 59.67 & 61.42 & 68.25 \\
\hline 't'- value & 2.64 & -1.22 & 1.73 & 3.66 & -2.45 & 0.00 & 0.33 & -0.39 & -0.42 & 2.93 & -1.79 & 0.00 \\
\hline Prob. of ' $t$ ' & 0.08 & 0.31 & 0.18 & 0.03 & 0.09 & 1.00 & 0.76 & 0.73 & 0.70 & 0.01 & 0.10 & 1.00 \\
\hline Significance & NS & NS & NS & $*$ & NS & NS & NS & NS & NS & $*$ & NS & NS \\
\hline
\end{tabular}

$*=$ Significant at $5 \%$ probability, NS = Not significant

Table 2: Reaction of intercropping cowpea with pearl millet infected with downy mildew (Sclerospora graminicola (Sacc.) Schroet) on grain yield for three years

\begin{tabular}{|c|c|c|c|c|c|c|c|c|c|c|c|c|}
\hline \multirow{3}{*}{$\begin{array}{l}\text { Year } \\
\text { Variety }\end{array}$} & \multicolumn{9}{|c|}{ Grain yield (kg/ha) } & \multirow{2}{*}{\multicolumn{3}{|c|}{ Combine }} \\
\hline & \multicolumn{3}{|c|}{2003} & \multicolumn{3}{|c|}{2004} & \multicolumn{3}{|c|}{2005} & & & \\
\hline & $\begin{array}{l}\text { LCIC } \\
9702 \\
\end{array}$ & Ex-Borno & Zango & $\begin{array}{l}\text { LCIC } \\
9702 \\
\end{array}$ & Ex-Borno & Zango & $\begin{array}{l}\text { LCIC } \\
9702 \\
\end{array}$ & Ex-Borno & Zango & $\begin{array}{c}\text { LCIC E } \\
9702 \\
\end{array}$ & Ex-Borno & Zango \\
\hline \multicolumn{13}{|l|}{ Parameter } \\
\hline Intercopping & 46.32 & 64.00 & 37.67 & 173.15 & 84.48 & 41.30 & 117.27 & 57.63 & 28.25 & 112.25 & 68.70 & 35.74 \\
\hline S/cropping & 52.30 & 83.72 & 98.32 & 95.85 & 45.78 & 27.78 & 48.60 & 74.68 & 16.30 & 65.58 & 68.06 & 47.47 \\
\hline 't'- value & -0.16 & -0.50 & -3.58 & 4.84 & 1.99 & 1.18 & 1.58 & -0.39 & 1.76 & 2.43 & 0.03 & -0.96 \\
\hline Prob. of ' $t$ ' & 0.88 & 0.66 & 0.04 & 0.02 & 0.14 & 0.32 & 0.21 & 0.72 & 0.18 & 0.03 & 0.98 & 0.36 \\
\hline Significance & NS & NS & $*$ & $*$ & NS & NS & NS & NS & NS & $*$ & NS & NS \\
\hline
\end{tabular}

$*=$ Significant at $5 \%$ probability, NS = Not significant 
The grain yield obtained showed that sole Zango and intercropped LCIC 9702 pearl millet varieties produced the highest grain yield in 2003 and 2004 respectively despite been inoculated with downy mildew spores solution. Similarly, combined analysis result showed that intercropped LCIC 9702 millet variety had more grain yield than other pearl millet varieties. This proved that improve pearl millet variety intercropped with cowpea as well as a local landrace planted solely yield better than other varieties. Yield advantages due to intercropping are commonly 20$30 \%$ but may be as much as $100 \%$ (Reddy and Willey 1980). These arise from differences in growth habit of the co-habiting crops and this research work supports the earlier statement, because majority of the varieties used yielded far less than expected when compared to intercropped LCIC 9702 pearl millet variety. Moreover, the intercropped variety was highly tolerant to downy mildew as compared to other varieties and therefore, yielded far better than others. Because the severity of grain loss depends on the prolonged presence of wet and cool weather during which the downy mildew sporulates profusely, cause

\section{REFERENCES}

Agrios, G. N. (2006). Plant Pathology. Fifth edition. Academic Press, 30 Corporate Drive, Suite 400, Barlington, MA 01803, USA.pp 156-267.

Bilquez, A P. (1979). General features of research on millet in Africa. Millet/Sorghum Research Seminar, Bombay, $31^{\text {st }}$ August- $4^{\text {th }}$ September, 1970. 17pp.

CBN, (1994). Central Bank of Nigeria. Statistical Bulletin 5 (1): 1-100.

FAO (1992). Food and Agriculture Organisation Production yearbook vol. 41. Rome, Italy. 200pp.

Grema, A. K. and Odo, P. E. (1998). Management Practices for Increasing and Stabilizing Pearl Millet Production in Nigeria. pp 76-86. In: Pearl Millet in Nigerian Agriculture: Production, utilization and Research Priorities. Emechebe, A. M., Ikwelle, M. C., Ajayi, O., Aminu Kano, M. and Anaso, A. B. eds). Proceedings of the Pre-season National Coordination and Planning Meeting of the Nationally Coordinated Research Programme for Pearl Millet, Maiduguri, 21-24 ${ }^{\text {th }}$ April 1997.

Hall, A. D. (2002). Fertilizers and Manures. Biotech Books, 1123/74, Tri Nager, Delhi 110 035, India. 21-138.

Harper, R. (1983). Principles of Arable Crop Production. Blackwell Science Ltd. Osney Mead, Oxford OX2 0EL.pp 230-232.

Ikwelle, M. C. (1998). Pearl Millet in Nigerian Agriculture. Pp 1-8. In: Pearl Millet in Nigerian Agriculture: production, utilization and research priorities. Proceedings of the Pre-season National Co-ordination and Planning Meeting of the Nationally Co-ordinated Research Programme on Pearl Millet, Maiduguri, Nigeria. $21^{\text {st }}-24^{\text {th }}$ April 1997.(Emechebe, A. .M , Ikwelle, M. C., Ajayi O., Aminu Kano, M. and Anaso, A. B. eds.).

KNARDA (2003). Kano South Senetorial District Agricultural Show, $16^{\text {th }}-17^{\text {th }}$ February 2003. Kano numerous new infections and spread into and rapidly kill young succulent tissues (Mehrotra and Aggarwal, 2003). Again, nitrogen abundance due to cowpea intercropping results in the production of more vegetative and succulent growth of plants (Agios, 2006) leading to high grain yield.

\section{CONCLUSION}

In conclusion, LCIC 9702 pearl millet variety intercropped with cowpea had more days to $50 \%$ heading than other varieties either planted sole or intercropped. Moreover,

maximum grain yield was however obtained from the sole Zango and intercropped LCIC 9702 pearl millet varieties.

\section{RECOMMENDATION}

It is therefore, recommended that farmers should plant pearl millet varieties either sole or intercrop with cowpea for early maturity instead of intercropping LCIC 9702 pearl millet variety with cowpea as well as Zango sole planted and cowpea intercropped LCIC 9702 for maximum grain yield.

Agricultural and Rural Development Authority, Kano State, Nigeria. 1p.

Mehrotra, R. S. and Aggarwal, A. (2003). Plant Pathology. Second edition. Tata Mc Graw-Hill Publishing Company, Limited, New Delhi, India. Pp 125-200.

National Research Council (1996). Lost of Crops in Africa Vol. 1. Grains. National Academy Press, Washington D. C., USA. Pp 100-120.

Nene, Y. L. and Singh, S. D. (1975). A Comprehensive review of downy mildew and ergot of pearl millet. International Crops Research Institute for the Semi-Arid Tropics, Hyderabad, India, 1975.

Nwasike, C C., Baker, E. F. and Eghareuba, P. N. (1982). The potential for improving millet (Pennisetm typhoides (Burm) Stapf and Hubband). in farming system of the Semi-Arid areas of Nigeria. Samaru Research Bulletin. 320pp.

Nwasike, C. C. (1988). Progress in millet improvement in Nigeria. Regional IAR/ICRISAT Pearl Millet Workshop, Zaria, Nigeria. 15-19 ${ }^{\text {th }}$ August 1988. 32pp.

Reddy, M. S. and Willey, R. W. (1980). Growth and resource use studies in an intercrop of pearl millet/groundnut. Field Crops Research, 4: 13-24.

Signh, S. D., Wilson, J. P., Navi, S. S., Talukdar, B. S., Hess, D. E. and Reddy, K. N. (1997). Screening Technique and sources of resistance to downy mildew and rust in pearl millet. Information Bulletin, 48: 51pp.

Williams, R. J., Singh, S. D. and Pawar, M. N. (1981). An improved field screening technique for downy mildew resistance in pearl millet. Plant Disease, 65: 239-241.

Yayock, J. Y., Lambin, G. and Owonubi, J. J. (1988). Crop Science and Production in Warm Climates. London, Macmillan. 307pp. 